\title{
CORRIGENDUM
}

\section{Oncoprotein ZNF322A transcriptionally deregulates alpha- adducin, cyclin D1 and p53 to promote tumor growth and metastasis in lung cancer}

J Jen, L-L Lin, F-Y Lo, H-T Chen, S-Y Liao, Y-A Tang, W-C Su, R Salgia, C-L Hsu, H-C Huang, H-F Juan and Y-C Wang

Oncogene (2017) 36, 4526; doi:10.1038/onc.2017.77; published online 3 April 2017

Correction to: Oncogene (2016) 35, 2357-2369; doi:10.1038/onc. 2015.296; published online 17 August 2015

Since the publication of the above article, the authors would like to correct the order of the authors in the author group as follows:

J Jen, L-L Lin, F-Y Lo, H-T Chen, S-Y Liao, Y-A Tang, W-C Su, R Salgia, C-L Hsu, H-C Huang, H-F Juan and Y-C Wang

The full and correct author listing is also reproduced above in the author group.
The authors would like to apologize to the readers for any inconvenience this may have caused.

This work is licensed under a Creative Commons Attributioncc) NonCommercial-ShareAlike 4.0 International License. The images or other third party material in this article are included in the article's Creative Commons license, unless indicated otherwise in the credit line; if the material is not included under the Creative Commons license, users will need to obtain permission from the license holder to reproduce the material. To view a copy of this license, visit http:// creativecommons.org/licenses/by-nc-sa/4.0/

(c) The Author(s) 2017 